\title{
The Effect of Environmental Conditions on Pollution Deposition and Canopy Leaching in Two Pine Stands (West Pomerania and Świętokrzyskie Mountains, Poland)
}

\author{
Rafał Kozłowski $^{1}{ }^{1}$, Robert Kruszyk ${ }^{2, *}$ (i) and Stanisław Małek ${ }^{3}$ \\ 1 Institute of Geography and Environmental Sciences, Jan Kochanowski University, 25-406 Kielce, Poland; \\ rafalka@ujk.edu.pl \\ 2 Institute of Geoecology and Geoinformation, Adam Mickiewicz University in Poznań, 61-680 Poznań, Poland \\ 3 Department of Ecology and Silviculture, University of Agriculture in Kraków, Faculty of Forestry, \\ 31-425 Krakow, Poland; rlmalek@cyf-kr.edu.pl \\ * Correspondence: rlk@amu.edu.pl
}

Received: 7 April 2020; Accepted: 8 May 2020; Published: 11 May 2020

\begin{abstract}
This study analyzed the effect of atmospheric deposition on canopy leaching processes in stands predominantly composed of Scots pines. The research was conducted in two stands: the first located in the southwestern part of the Świętokrzyskie Mountains in the area known as Białe Zagłębie (Malik), and the second in the northwestern part of Poland in Western Pomerania (Czarne). The study was conducted in the hydrological years 2010-2013. The goal of the study was to assess the chemical transformation of precipitation as a result of various human activities. In Malik, the main factor that determined the physicochemical and chemical properties of throughfall was the cement/lime dust emitted by nearby industrial plants, which not only affected the quantity of deposit but also contributed to the alkalization process of throughfall. By contrast, the main source of pollution in Czarne, where local emitters are absent, was long-distance transport. We conducted a principal component analysis (PCA) in both stands that produced components representing local pollution (Malik) and long-distance transport (Czarne). For the stand in Czarne, sea aerosols were an important source of $\mathrm{Na}^{+}$and $\mathrm{Cl}^{-}$ions in precipitation. In both stands, the highest enrichment ratio (ER) values were recorded for $\mathrm{K}^{+}$ions. The contribution of leaching processes to the bulk deposition of $\mathrm{K}^{+}$ions in Malik was $85.8 \%$, whereas in Czarne, it was $73.8 \%$. Regardless of the degree of anthropopressure, the intensity of quantitative and qualitative transformation in pine stands was comparable.
\end{abstract}

Keywords: throughfall; bulk precipitation; ion deposition; canopy budget model; Scots pine

\section{Introduction}

Atmospheric deposition is considered one of the controlling factors that determine the circulation of matter in forest ecosystems. As a result of contact with the surface of plants, rainwater undergoes a transformation that depends not only on species composition (conifers, deciduous trees) but also on the degree of atmospheric air pollution. In the temperate climatic zone, vegetation strongly affects the biogeochemical cycles of elements. These cycles are associated with water circulation and the chemical composition of water and dust that reaches tree stands, among other processes. Atmospheric pollutants affect the chemical composition of rain both directly, through their chemical properties, and indirectly, by leaching compounds deposited on the surface of needles or leaves.

As a result of alkaline pollutants emitted over the last 50 years, significant changes in rainwater occurred in Malik [1], altering the floristic composition of forest communities as well as other 
components of the natural environment including soils [1,2] and selected bioindicators, such as pine needles and lichens [3,4]. The results of precipitation chemistry monitoring since the end of the 1990s confirm a systematic decrease in both precipitation's level of electrical conductivity (EC) and its ion concentration. The observed low ion concentrations in precipitation reflect the better air quality in northern Poland than in the south. As a result of reductions in the domestic emission of sulfur, precipitation $\mathrm{pH}$ has increased in the studied area and a greater role in the acidification process of nitrogen compounds [5].

When rainwater contacts plant surfaces, materials deposited on the surfaces wash out the rainwater and change its physicochemical properties and chemical composition. Furthermore, extensive ion-exchange processes take place between rainwater and trees in the canopy $[1,6,7]$. In addition to these changes in chemical composition, there are also changes in the amount of water that reaches the soil due to interception by the canopy. The rainfall that reaches the soil is characterized by significant variability that depends on the species composition of the forest; the structure, levels, density, and shape of the canopy [6,8-10]; the degree of compaction of leaves and needles; and distance from the tree trunk $[11,12]$.

Research on the dynamics of nutrient cycling in forest stands indicates significant quantitative and qualitative differences between bulk precipitation and throughfall $[6,11,13-18]$. The species composition of a stand and the acidity of precipitation are important factors that modify the intensity of precipitation transformation in a forest $[6,11]$. It is assumed that coniferous trees modify the chemical properties of precipitation much more than deciduous trees [19] and thus have a stronger effect on the load of nutrients supplied to the soil, which in turn contributes to an increase in the rate of soil leaching $[6,11]$. The intensity of the leaching process depends, among others, on species composition [8,10], size of immission [20], and size of deposition [1]. According to Ukonmaanaho and Star [21], the leaching process mainly concerns monovalent $\mathrm{K}^{+}$ions, which are more mobile and less bound in cell walls, chloroplasts, and enzymes [22] than divalent cations, and whose intensity depends on the size of acid deposition.

The main research problem was to determine the deposition and processes occurring in pine stands in areas with varying degrees of atmospheric air pollution.

The manuscript tested the following hypothesis: the intensity of leaching components from pine tree crowns depends on cement-lime dust, emissions from agricultural areas, and marine aerosols.

\section{Materials and Methods}

\subsection{Study Site}

The research was conducted in two mixed stands composed predominantly of Scots pines (Table 1). Both research plots belong to the measurement network of the Integrated Monitoring Program (ICP; Czarne and Malik correspond to PL06 and PL09, respectively). The first, Malik, is located in the southwestern part of the Świettokrzyskie Mountains in the area known as Białe Zagłębie, while the other, Czarne, is located in Western Pomerania (Figure 1). The Czarne plot is situated in an area without local sources of industrial pollution. The dominant forms of land cover are arable land (43.4\%) and forests (34.6\%) under intensive management [5]. The largest urban center, Szczecinek (population 40,366 ), is located $15 \mathrm{~km}$ from the plot and can be a source of municipal pollution. Impact of pollutants from Szczecinek is limited only to the situation of inflow of air masses from the southeast direction. The share of this sector in a year is $5 \%$ on average.

Acidification and the ion concentration in rainwater are declining in the research area due to the reduction of $\mathrm{SO}_{2}$ emissions that has been observed in recent years [5]. From 2010 to 2013, the annual mean concentrations of $\mathrm{SO}_{2}$ and $\mathrm{NO}_{2}$ ranged from 3.32 to $5.05 \mu \mathrm{g} \cdot \mathrm{m}^{-3}$ and from 2.04 to $6.31 \mu \mathrm{g} \cdot \mathrm{m}^{-3}$, respectively [5]. 
In the Białe Zagłebie area, the cement/lime industry is a major source of dust emissions. In the years 2010-2013, these plants emitted a total of 1487.1 tonnes of dust into the atmosphere, of which lime plants were $46.2 \%$ and cement plants were $53.8 \%$.

Table 1. Characteristics of the experimental stands.

\begin{tabular}{|c|c|c|}
\hline Parameters & Czarne & Malik \\
\hline Location & $53.7471^{\circ} \mathrm{N}, 16.5529^{\circ} \mathrm{E}$ & $50.8144^{\circ} \mathrm{N}, 20.4966^{\circ} \mathrm{E}$ \\
\hline Altitude ( $m$ above sea level) & 152 & 267 \\
\hline $\begin{array}{l}\text { Species composition at sampling } \\
\text { site }(\%)\end{array}$ & $\begin{array}{c}\text { Pinus sylvestris (86), Quercus robur } \\
\text { (7), Fagus sylvatica (5), Betula } \\
\text { pendula (2) }\end{array}$ & $\begin{array}{l}\text { Pinus sylvestris (52), Carpinus } \\
\text { betulus (27) Fagus sylvatica (21) }\end{array}$ \\
\hline Canopy cover (\%) & 70 & 60 \\
\hline Trees age (year) ${ }^{1}$ & $\begin{array}{c}\text { Pinus sylvestris (92), Quercus robur } \\
\text { (20), Fagus sylvatica (40), Betula } \\
\text { pendula (20) }\end{array}$ & $\begin{array}{l}\text { Pinus sylvestris (80), Carpinus } \\
\text { betulus (50), Fagus sylvatica (60) }\end{array}$ \\
\hline Trees height $(\mathrm{m})^{1}$ & $\begin{array}{c}\text { Pinus sylvestris (17-27), Quercus } \\
\text { robur (5-10), Fagus sylvatica (10-15), } \\
\text { Betula pendula (2-10) }\end{array}$ & $\begin{array}{c}\text { Pinus sylvestris (25-35), Carpinus } \\
\text { betulus (20-25), Fagus sylvatica } \\
\text { (20-28) }\end{array}$ \\
\hline Soils & $\begin{array}{l}\text { Spodic Udipsamments }{ }^{2} \text {, Albic } \\
\text { Brunic Arenosol (Dystric) }\end{array}$ & $\begin{array}{c}\text { Spodic Udipsamments }{ }^{2} \text {, Albic } \\
\text { Brunic Arenosol (Dystric) }\end{array}$ \\
\hline Soils texture & Sand & Sand \\
\hline Pines average breast height $(\mathrm{cm})^{1}$ & $11-55$ & $14-21$ \\
\hline $\begin{array}{l}\text { Average annual air temperature } \\
\text { (2010-2013) }\end{array}$ & $7.1^{\circ}-8.1^{\circ}$ & $6.7^{\circ}-7.7^{\circ}$ \\
\hline $\begin{array}{c}\text { Average annual total of } \\
\text { precipitation }(2010-2013)(\mathrm{mm})\end{array}$ & 692.8 & 575.0 \\
\hline
\end{tabular}

${ }^{1}$ Data for 2013, ${ }^{2}$ soil taxonomy [23], ${ }^{3}$ World Reference Base for Soil Resources [24].

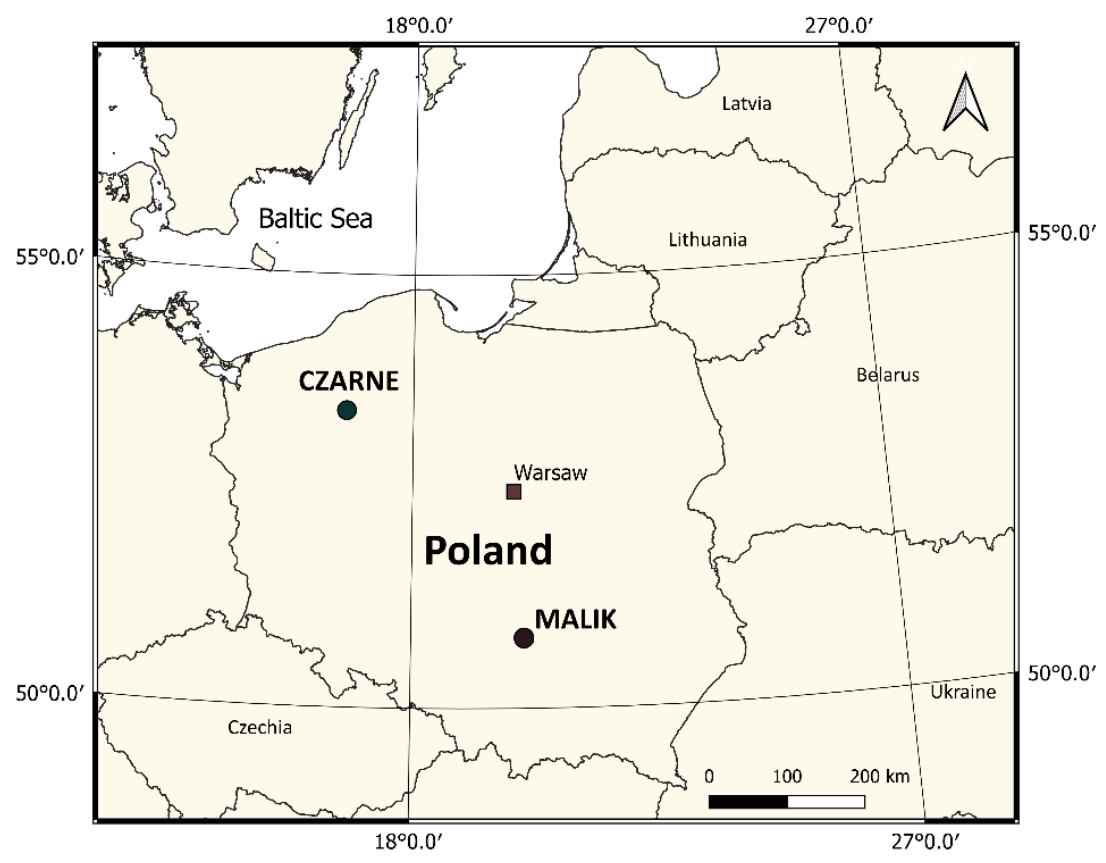

Figure 1. Location of the sampling site.

The Malik plot is situated $2.5 \mathrm{~km}$ from the Dyckerhoff cement plant in Nowiny and $5 \mathrm{~km}$ from the lime plant in Sitkówka-Nowiny. From 2010 to 2013, the mean annual concentration of PM10 in 
Nowiny ranged from 32.0 to $40.3 \mu \mathrm{g} \cdot \mathrm{m}^{-3}$, with a maximum daily mean of $186.6 \mu \mathrm{g} \cdot \mathrm{m}^{-3} \mathrm{observed}$ in 2012. The particulate matter in this area is highly alkaline $(\mathrm{pH}>11)$, and calcium and magnesium ions are predominant [1]. In the analyzed period, the annual mean concentration of $\mathrm{NO}_{2}$ at Nowiny ranged from 15.5 to $26.4 \mu \mathrm{g} \cdot \mathrm{m}^{-3}[1]$.

\subsection{Sampling and Laboratory Analyses}

\subsubsection{Rainfall and Throughfall Measurements}

The results presented here cover a period of four hydrological years: 2010, 2011, 2012, and 2013. The measurement system included bulk precipitation (BP) and throughfall (TF). In Malik, throughfall was measured with five collectors with a total collection surface of $5670 \mathrm{~cm}^{2}$ arranged in an " $X^{\prime \prime}$ shape at a height of $1 \mathrm{~m}$ above the ground. In the second research plot, Czarne, the measuring system included 12 collectors with a total area of $1592 \mathrm{~cm}^{2}$ regularly spaced on a grid. The inlet of each collector was placed at a height of $1 \mathrm{~m}$ above the ground. In both cases, the collectors were made of plastics (PTFE) that did not affect the chemical composition of rainwater. The collectors in the field were exposed monthly. In both the cases of bulk precipitation and throughfall, precipitation samples were collected after a monthly exposure of collectors in the field.

\subsubsection{Chemical Analysis}

Laboratory analyses measured the amount of precipitation and basic physicochemical parameters including electrical conductivity (EC), $\mathrm{pH}$, and the concentrations of dominant ions (chlorides, sulfates, nitrates, sodium, magnesium, potassium, ammonium, and calcium). The amount of precipitation, $\mathrm{pH}$, and EC were measured for each collector separately. The quantification of the other parameters was based on mixed samples. Samples were mixed proportionally, taking into account the precipitation amount at individual positions. After filtration, the samples were stored in a refrigerator at $4{ }^{\circ} \mathrm{C}$. Chemical analyses were conducted in laboratories included in the Integrated Monitoring of the Natural Environment network of Poland. Samples from Malik were analyzed in the Environmental Research Laboratory of Jan Kochanowski University in Kielce, whereas samples from the Czarne plot were analyzed in the laboratory of the Geoecological Station at Adam Mickiewicz University in Storkowo (Table 2). During the research period, both laboratories participated in an inter-calibration process and the results obtained by each did not differ. Artificial rain samples from inter-calibration experiments organized by WMO/GAW (World Meteorological Organization/Global Atmosphere Watch Programme) were used. The difference in the results obtained in relation to the expected results was in the range of $+/-10 \%$.

Table 2. Experimental parameters, methods, and units.

\begin{tabular}{|c|c|c|c|}
\hline \multirow{2}{*}{ Variable } & \multicolumn{2}{|c|}{ Method and Instrument } & \multirow{2}{*}{ Reporting Unit } \\
\hline & Czarne & Malik & \\
\hline $\mathrm{pH}, \mathrm{EC}$ & Potentiometry & Potentiometry & $\mathrm{pH}$ unit, $\mu \mathrm{S} \cdot \mathrm{cm}^{-1}$ \\
\hline $\mathrm{Cl}^{-}, \mathrm{NO}_{3}{ }^{-}, \mathrm{SO}_{4}{ }^{2-}$ & $\begin{array}{l}\text { Ion chromatography (DX-120 } \\
\text { by Dionex) }\end{array}$ & \multirow{4}{*}{$\begin{array}{l}\text { Ion chromatography } \\
\text { (Dionex ICS 3000) }\end{array}$} & \multirow{4}{*}{$\mathrm{mg} \cdot \mathrm{dm}^{-3}$} \\
\hline $\mathrm{NH}_{4}^{+}$ & $\begin{array}{l}\text { Nessler spectrophotometric method } \\
\text { (Spekol 1100, Carl Zeiss) }\end{array}$ & & \\
\hline $\mathrm{Na}^{+}, \mathrm{K}^{+}$ & $\begin{array}{l}\text { AES Flame (SpectrAA-20 } \\
\text { plus, Varian) }\end{array}$ & & \\
\hline $\mathrm{Ca}^{2+}, \mathrm{Mg}^{2+}$ & $\begin{array}{l}\text { AAS Flame (SpectrAA-20 } \\
\text { plus, Varian) }\end{array}$ & & \\
\hline
\end{tabular}




\subsection{Data Analysis}

\subsubsection{Statistical Analysis}

We calculated a weighted mean for each parameter, where the weight was the amount of precipitation. Unless otherwise stated, the reported statistics covered the entire measurement period and were calculated on the basis of monthly data. We performed statistical analysis to determine the statistical significance of differences between depositions under the canopy and in open areas. To identify the supply sources of chemical components in the analyzed water samples, we performed a principal component analysis (PCA) with Varimax factor rotation.

Variables were appropriately standardized before the PCA was performed. Finally, Pearson correlation was tested to determine the relationship between ion distributions.

\subsubsection{Enrichment Ratio}

In order to determine the degree of precipitation transformation in the forest, an enrichment ratio (ER) was applied (the ratio of the load of an ion in precipitation under the canopy to its load in precipitation in the open area).

\subsubsection{Canopy Budget Modelling}

To determine the loads of ions $\left(\mathrm{K}^{+}, \mathrm{Ca}^{2+}, \mathrm{Mg}^{2+}\right)$ leached out of the canopy, we used the canopy budget model [25-28].

This model is based on two assumptions:

- $\mathrm{Na}^{+}$ions are not subject to any processes during the infiltration of precipitation through the tree canopy; and

- $\quad$ Particles containing $\mathrm{Ca}^{2+}, \mathrm{Mg}^{2+}$, and $\mathrm{K}^{+}$ions have the same size as particles containing $\mathrm{Na}^{+}$.

These assumptions make it possible to estimate the DDF (dry deposition factor) for these ions according to the following formula [23]:

$$
\mathrm{DDF}=\left(\mathrm{TF}_{\mathrm{Na}}+\mathrm{SF}_{\mathrm{Na}}-\mathrm{BP}_{\mathrm{Na}}\right) / \mathrm{BP}_{\mathrm{Na}}
$$

where $\mathrm{TF}_{\mathrm{Na}}$ is the throughfall flux of sodium, $\mathrm{SF}_{\mathrm{Na}}$ is the stemflow flux of sodium, and $\mathrm{BP} \mathrm{Na}_{\mathrm{Na}}$ is the bulk precipitation flux of $\mathrm{Na}^{+}$.

The amount of leaching of individual $\mathrm{CL}_{x}$ ions was calculated on the basis of the following formula [27]:

$$
\mathrm{CL}_{\mathrm{x}}=\mathrm{TF}_{\mathrm{x}}+\mathrm{SF}_{\mathrm{x}}-\mathrm{BP}_{\mathrm{x}}-\mathrm{DD}_{\mathrm{x}}
$$

where $\mathrm{DD}_{\mathrm{x}}$ is the ion loads from the wash-off of dry deposition from the surface of plants.

\subsubsection{Neutralisation Indicators of Acidic Compounds}

Some of the cations $\left(\mathrm{Ca}^{2+}, \mathrm{Mg}^{2+}, \mathrm{K}^{+}\right)$and anions $\left(\mathrm{SO}_{4}{ }^{2-}\right)$ measured over land partially originate from sea salt. The fractions of these ions, which originate from the sea, did not play any role in deciding acidity/alkalinity of rainwater sample. The non-sea-salt (nss) fraction ions concentrations were calculated as follows [29,30]:

$$
\mathrm{No}-\text { sea }- \text { salt }(\text { nss })=X_{\text {bulk precipitation }}-\mathrm{Na}_{\text {bulk precipitation }} \cdot \frac{X}{\mathrm{Na}^{+}} \text {seawater }
$$

where $\mathrm{X}=\mathrm{SO}_{4}{ }^{2-}, \mathrm{K}^{+}, \mathrm{Mg}^{2+}, \mathrm{Ca}^{2+}$. 
Neutralization factors $\left(\mathrm{NF}_{\mathrm{x}}\right)$ of the different alkaline constituents were calculated using the formula suggested by Parashar et al. [31]:

$$
\mathrm{NFX}_{\mathrm{X}}=\frac{\mathrm{X}}{\mathrm{nssSO}_{4}^{2-}+\mathrm{NO}_{3}^{-}}
$$

where $\mathrm{X}=\mathrm{nssCa}^{2+}, \mathrm{nssMg}^{2+}, \mathrm{nssK}^{+}, \mathrm{NH}_{4}{ }^{+}$.

Considering both $\mathrm{SO}_{4}{ }^{2-}$ and $\mathrm{NO}_{3}{ }^{-}$as the main acidifying components of rain. Fractional acidity (FA) was computed according to Balasubramanian et al. [32] as

$$
\text { Fractional acidity }(\mathrm{FA})=\frac{\mathrm{H}^{+}}{\mathrm{nssSO}_{4}^{2-}+\mathrm{NO}_{3}^{-}}
$$

$\mathrm{FA}=1$ indicates that the acidity is not neutralized, whereas $\mathrm{FA}=0$ indicates that the rainwater acidity generated by these strong acids is completely neutralized.

Relative contribution of $\mathrm{NO}_{3}{ }^{-}$to the acidification was calculated using a ratio

$$
\text { Contribution indicator of acidic factors }=\frac{\mathrm{NO}_{3}^{-}}{\mathrm{nssSO}_{4}^{2-}}
$$

All concentrations were expressed in $\mu \mathrm{Eq} \cdot \mathrm{dm}^{-3}$.

\section{Results}

\subsection{Canopy Impacts on Rainwater Fluxes}

During the study period, the average annual bulk precipitation was 692.8 (579.9-784.8) $\mathrm{mm}$ for the Czarne plot and 575.0 (476.5-736.4) $\mathrm{mm}$ for the Malik plot. The average throughfall was $503.5 \mathrm{~mm}$ for Czarne and $410.3 \mathrm{~mm}$ for Malik. Values for individual years ranged from $408.1 \mathrm{~mm}$ (2013) to $581.7 \mathrm{~mm}$ (2010) for Czarne, and from $372.7 \mathrm{~mm}$ (2012) to $547.2 \mathrm{~mm}$ (2010) for Malik. In both stands, the distribution of the amount of throughfall was strongly correlated with the distribution of precipitation (Figure 2).
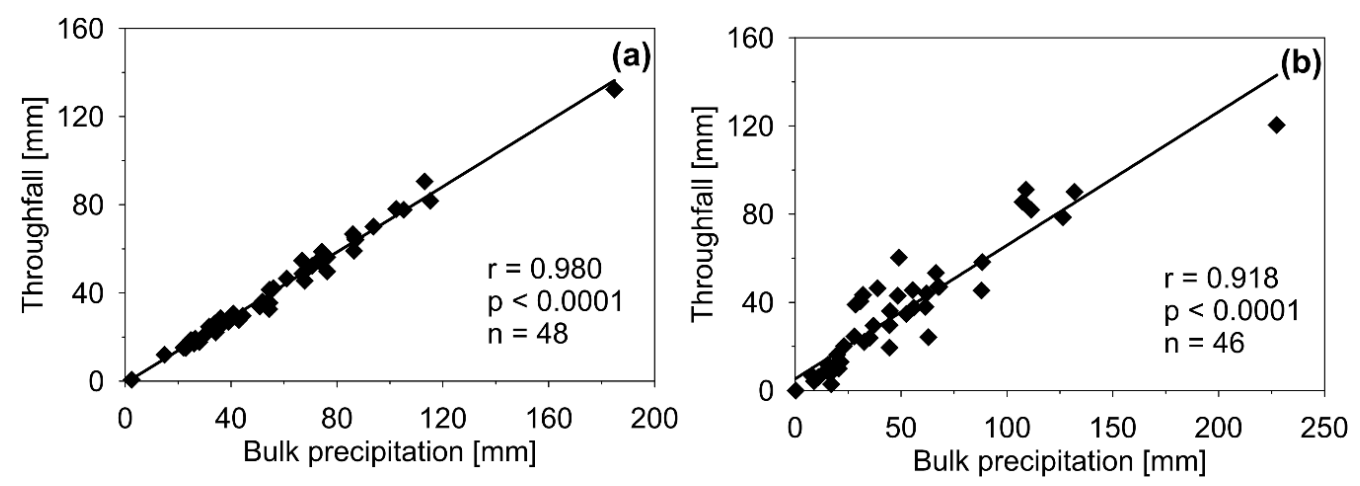

Figure 2. Linear correlations between bulk precipitation and throughfall in the Czarne (a) and in the Malik (b). $r$ is the Pearson correlation coefficient, $p$ is the significance value, $n$ is the sample size.

During the study period, the mean standard deviation of canopy interception was $28.7 \% \pm 8.5 \%$ (Czarne) and $27.1 \% \pm 24.7 \%$ (Malik). Extreme values ranged from $18.1 \%$ to $75.0 \%$ (Czarne) and from $-36.9 \%$ to $83.6 \%$ (Malik). In some instances, monthly throughfall for the Malik plot was observed as being higher than monthly precipitation in the Malik plot's open area (canopy interception less than 0\%). From 2010 to 2013, there were five such cases: in January and February $2010(-31.5 \%$ and $-18.9 \%$, respectively), in November $2011(-35.3 \%)$, in August $2012(-23.0 \%)$, and in April $2013(-36.9 \%)$. 


\subsection{Canopy Impacts on Rainwater Chemistry and Deposition Fluxes}

The weighted mean EC of bulk precipitation during the study period, taking into account the standard deviation at Malik, was $37.6 \pm 23.2 \mu \mathrm{S} \cdot \mathrm{cm}^{-1}$ and $13.7 \pm 8.1 \mu \mathrm{S} \cdot \mathrm{cm}^{-1}$ for the Czarne plot. Under the canopy, the weighted average EC increased in comparison with bulk precipitation and was $65.9 \pm 61.5 \mu \mathrm{S} \cdot \mathrm{cm}^{-1}$ in the Malik plot and $34.4 \pm 50.5 \mu \mathrm{S} \cdot \mathrm{cm}^{-1}$ in the Czarne plot (Figure 3a).
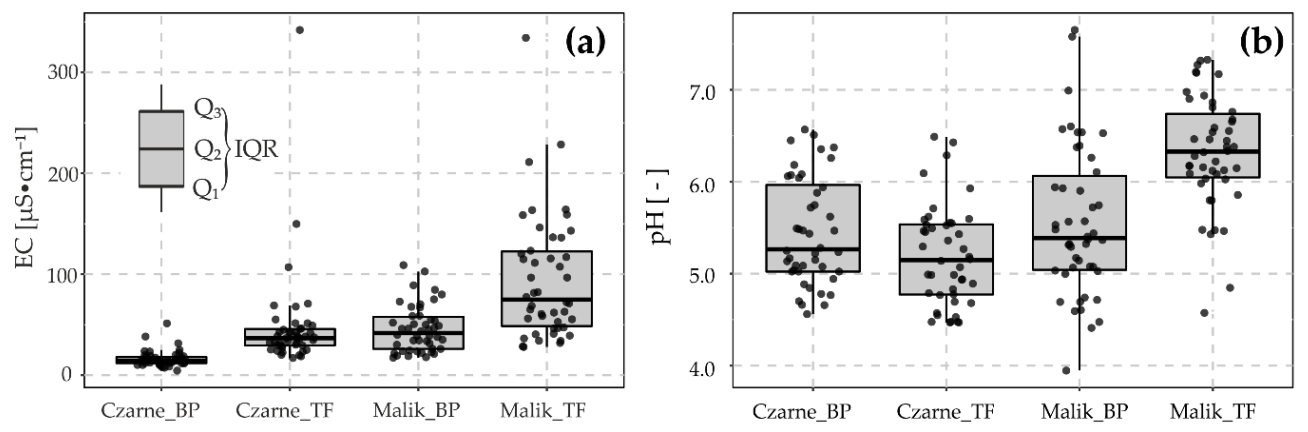

Figure 3. Monthly values of electrical conductivity (EC) (a) and $\mathrm{pH}$ (b) for bulk precipitation (BP) and throughfall (TF). Boxplots indicate the lower quartile (Q1), median (Q2), upper quartile (Q3), and interquartile range (IQR).

The weighted mean $\mathrm{pH}$ of bulk precipitation in the period from 2010 to 2013 was 4.98 in the Malik plot and 5.16 in the Czarne plot (Figure 3b). After passing the canopy, the $\mathrm{pH}$ of the throughfall in Malik increased by 0.93 units and reached 5.91, with extreme values of 4.57 (January 2013) and 7.33 (December 2009). In Czarne, the $\mathrm{pH}$ value of the throughfall dropped by 0.23 units (4.93). Extreme values ranged from 4.47 (March 2010) to 6.49 (March 2011).

For all tested ions on both plots, except for hydrogen ions, the observed weighted mean concentrations in throughfall exceeded the concentrations in bulk precipitation (Table 3).

The concentrations of bulk precipitation and throughfall in the Malik plot were many times higher than the concentrations observed in the Czarne plot (Figure 4). For throughfall, the greatest differences were noted for $\mathrm{SO}_{4}{ }^{2-}$, with concentrations more than eight times higher (8.8); $\mathrm{NO}_{3}{ }^{-}$, with concentrations more than six times higher (6.2); and $\mathrm{Ca}^{2+}$, with concentrations more than seven times higher (7.2). Similar concentrations were observed for $\mathrm{Na}^{+}$. For $\mathrm{EC}$, the bulk precipitation values were almost three times higher (2.7) in the Malik plot than in the Czarne plot, whereas the throughfall values were almost twice as high (1.9). Higher values were only observed in the Czarne plot compared to the Malik plot for $\mathrm{NH}_{4}{ }^{+}$(bulk precipitation and throughfall) and $\mathrm{H}^{+}$(throughfall). Taking into account the concentrations expressed in $\mu \mathrm{Eq} \cdot \mathrm{dm}^{-3}$, the following series of anions and cations were obtained for throughfall: $\mathrm{Cl}^{-}>\mathrm{NO}_{3}{ }^{-}>\mathrm{SO}_{4}{ }^{2-} ; \mathrm{NH}_{4}{ }^{+}>\mathrm{Ca}^{2+}>\mathrm{Na}^{+}>\mathrm{K}^{+}>\mathrm{Mg}^{2+}>\mathrm{H}^{+}$for Czarne, and $\mathrm{SO}_{4}{ }^{2-}>$ $\mathrm{NO}_{3}^{-}>\mathrm{Cl}^{-} ; \mathrm{Ca}^{2+}>\mathrm{K}^{+}>\mathrm{Mg}^{2+}>\mathrm{Na}^{+}>\mathrm{NH}_{4}^{+}>\mathrm{H}^{+}$for Malik.

For both stands, statistically significant dependencies were found between ion concentrations, EC, and the amount of throughfall (Table 4). These were inversely proportional dependences that indicated the increase EC as a result of solution concentration. We observed no statistically significant relationships between $\mathrm{H}^{+}$and $\mathrm{SO}_{4}{ }^{2-}$ or $\mathrm{H}^{+}$and $\mathrm{NO}_{3}{ }^{-}$in throughfall on either plot. However, a statistically significant and inversely proportional dependence between the distributions of $\mathrm{H}^{+}$and $\mathrm{NH}_{4}{ }^{+}$was observed in Czarne. No similar dependence was observed in Malik, which may indicate that $\mathrm{NH}_{4}{ }^{+}$plays a less important role in neutralising throughfall acidity. For throughfall in both plots, there were statistically significant dependencies between the distributions of $\mathrm{Cl}^{-}$and $\mathrm{Na}^{+}, \mathrm{K}^{+}$and $\mathrm{Mg}^{2+}$, and $\mathrm{K}^{+}$and $\mathrm{Ca}^{2+}$. 
Table 3. Statistical descriptors of the chemical composition of bulk precipitation (BP) and throughfall (TF).

\begin{tabular}{|c|c|c|c|c|c|c|c|c|c|c|}
\hline & $\mathrm{SO}_{4}{ }^{2-}$ & $\mathrm{NO}_{3}{ }^{-}$ & $\mathrm{Cl}^{-}$ & $\mathrm{Ca}^{2+}$ & $\mathrm{K}^{+}$ & $\mathrm{NH}_{4}^{+}$ & $\mathrm{Mg}^{2+}$ & $\mathrm{Na}^{+}$ & $\mathrm{pH}$ & EC \\
\hline & \multicolumn{8}{|c|}{$\mathrm{mg} \cdot \mathrm{dm}^{-3}$} & - & $\mu S \cdot \mathrm{cm}^{-1}$ \\
\hline \multicolumn{11}{|c|}{ Malik—bulk precipitation $\mathrm{BP}$} \\
\hline Min & 1.76 & 0.37 & 0.09 & 1.21 & 0.12 & $<0.01$ & 0.25 & $<0.01$ & 3.95 & 17.3 \\
\hline $\begin{array}{l}\text { Mean } \\
\pm \text { SD }\end{array}$ & $\begin{array}{c}7.40 \pm \\
8.85\end{array}$ & $\begin{array}{c}3.32 \pm \\
4.17\end{array}$ & $\begin{array}{c}2.92 \pm \\
1.48\end{array}$ & $\begin{array}{c}3.99 \pm \\
3.32\end{array}$ & $\begin{array}{c}0.50 \pm \\
0.39\end{array}$ & $\begin{array}{c}0.67 \pm \\
0.79\end{array}$ & $\begin{array}{c}0.77 \pm \\
0.47\end{array}$ & $\begin{array}{c}1.47 \pm \\
1.72\end{array}$ & 4.98 & $37.6 \pm 23.2$ \\
\hline $\mathrm{Q}_{2}$ & 5.69 & 2.35 & 2.58 & 3.86 & 0.40 & 0.57 & 0.75 & 0.98 & 5.39 & 41.7 \\
\hline $\operatorname{Max}$ & 39.3 & 19.0 & 7.40 & 14.96 & 1.67 & 3.65 & 2.52 & 7.84 & 7.70 & 109 \\
\hline$N$ & 43 & 43 & 41 & 42 & 43 & 43 & 43 & 43 & 46 & 46 \\
\hline \multicolumn{11}{|c|}{ Malik—throughfall TF } \\
\hline Min & 4.27 & 2.24 & 0.22 & 0.79 & 0.30 & $<0.01$ & 0.28 & 0.01 & 4.57 & 28.0 \\
\hline $\begin{array}{l}\text { Mean } \\
\pm \text { SD }\end{array}$ & $\begin{array}{c}17.3 \pm \\
21.1\end{array}$ & $\begin{array}{c}17.3 \pm \\
21.3\end{array}$ & $\begin{array}{c}3.29 \pm \\
2.45\end{array}$ & $\begin{array}{c}8.98 \pm \\
9.57\end{array}$ & $\begin{array}{c}4.96 \pm \\
4.36\end{array}$ & $\begin{array}{c}1.26 \pm \\
1.29\end{array}$ & $\begin{array}{c}1.41 \pm \\
0.84\end{array}$ & $\begin{array}{c}1.64 \pm \\
1.93\end{array}$ & 5.91 & $65.9 \pm 61.5$ \\
\hline $\mathrm{Q}_{2}$ & 15.0 & 21.3 & 3.39 & 10.25 & 3.83 & 1.39 & 1.41 & 1.26 & 6.33 & 74.8 \\
\hline $\operatorname{Max}$ & 122.8 & 90.2 & 11.2 & 55.2 & 20.3 & 6.57 & 4.79 & 8.79 & 7.33 & 334 \\
\hline$N$ & 43 & 43 & 41 & 42 & 43 & 43 & 43 & 43 & 46 & 46 \\
\hline \multicolumn{11}{|c|}{ Czarne-bulk precipitation BP } \\
\hline Min & 0.45 & 0.60 & 0.19 & 0.16 & 0.08 & 0.12 & $<0.01$ & 0.23 & 4.56 & 4.5 \\
\hline $\begin{array}{l}\text { Mean } \\
\pm \text { SD }\end{array}$ & $\begin{array}{c}0.96 \pm \\
0.88\end{array}$ & $\begin{array}{c}1.50 \pm \\
1.12\end{array}$ & $\begin{array}{c}0.60 \pm \\
0.35\end{array}$ & $\begin{array}{c}0.79 \pm \\
0.64\end{array}$ & $\begin{array}{c}0.27 \pm \\
0.26\end{array}$ & $\begin{array}{c}0.69 \pm \\
0.87\end{array}$ & $\begin{array}{c}0.13 \pm \\
0.06\end{array}$ & $\begin{array}{c}0.63 \pm \\
0.32\end{array}$ & 5.16 & $13.7 \pm 8.1$ \\
\hline $\mathrm{Q}_{2}$ & 0.88 & 1.50 & 0.62 & 0.78 & 0.23 & 0.76 & 0.12 & 0.62 & 5.26 & 14.4 \\
\hline Max & 6.15 & 6.95 & 1.64 & 3.59 & 1.25 & 4.22 & 0.35 & 2.32 & 6.57 & 51.3 \\
\hline$N$ & 46 & 46 & 46 & 46 & 46 & 45 & 46 & 46 & 44 & 45 \\
\hline \multicolumn{11}{|c|}{ Czarne-throughfall TF } \\
\hline Min & 0.53 & 0.43 & 0.54 & 0.56 & 0.50 & 0.46 & 0.18 & 0.58 & 4.47 & 17.0 \\
\hline $\begin{array}{l}\text { Mean } \\
\pm \text { SD }\end{array}$ & $\begin{array}{c}1.97 \pm \\
7.22\end{array}$ & $\begin{array}{c}2.81 \pm \\
4.45\end{array}$ & $\begin{array}{c}2.01 \pm \\
2.34\end{array}$ & $\begin{array}{c}1.24 \pm \\
1.97\end{array}$ & $\begin{array}{c}2.06 \pm \\
3.34\end{array}$ & $\begin{array}{c}2.41 \pm \\
1.86\end{array}$ & $\begin{array}{c}0.36 \pm \\
0.49\end{array}$ & $\begin{array}{c}1.26 \pm \\
0.72\end{array}$ & 4.93 & $34.4 \pm 50.5$ \\
\hline $\mathrm{Q}_{2}$ & 2.08 & 2.90 & 2.03 & 1.40 & 1.79 & 2.44 & 0.38 & 1.32 & 5.15 & 36.7 \\
\hline$\hat{\operatorname{Max}}$ & 50.3 & 27.6 & 15.3 & 14.2 & 22.6 & 8.04 & 3.59 & 4.67 & 6.49 & 342 \\
\hline$N$ & 46 & 46 & 46 & 46 & 46 & 45 & 46 & 46 & 44 & 45 \\
\hline
\end{tabular}



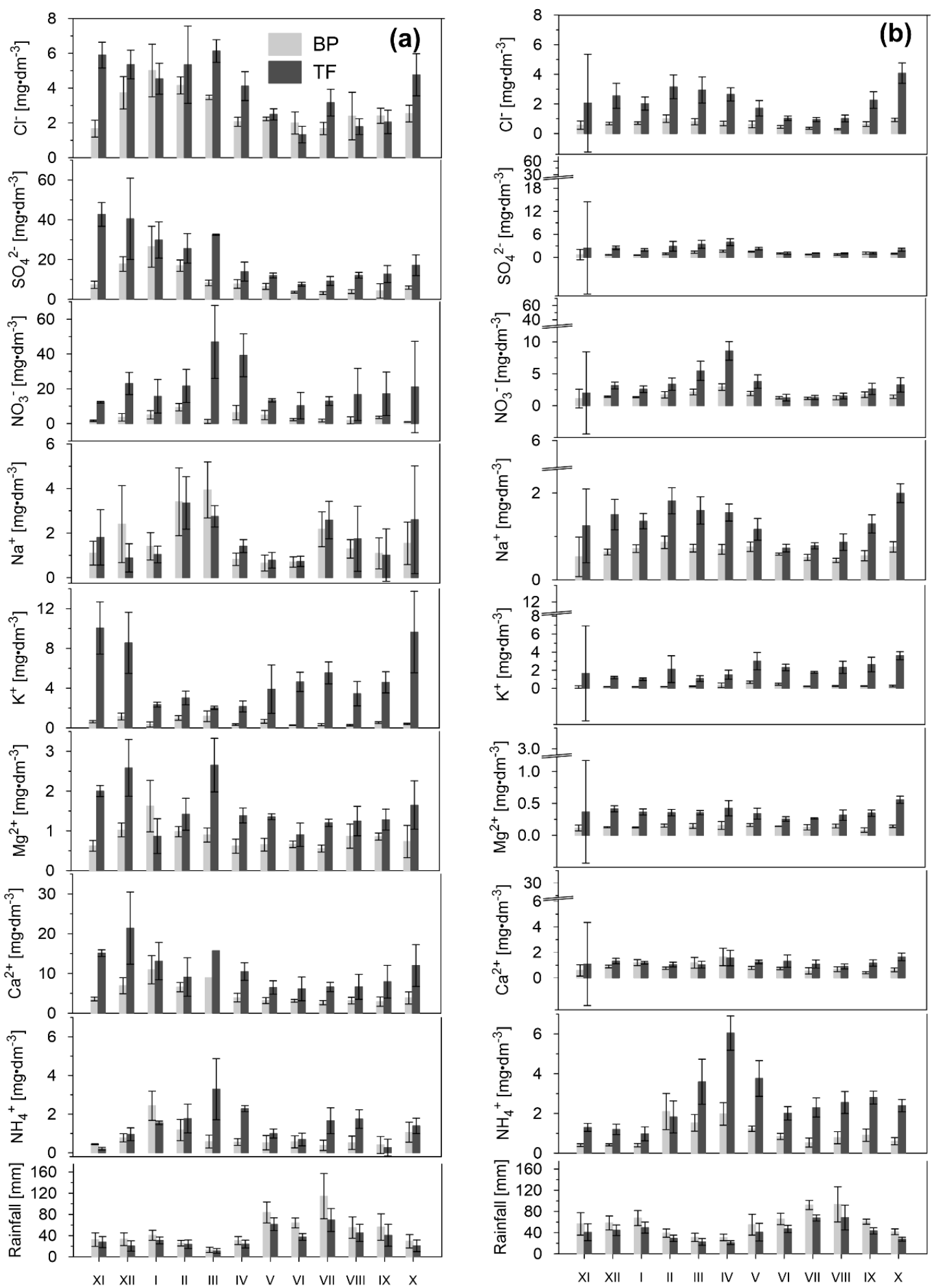

Figure 4. Monthly variation of volume-weighted mean \pm standard error ion concentrations in bulk precipitation (BP) and throughfall (TF) in Malik (a) and in Czarne (b). For comparison, monthly rainfall is presented at the bottom of the graph as well. 
Table 4. Ion pair correlations in throughfall (regular represents Malik, bold represents Czarne).

\begin{tabular}{|c|c|c|c|c|c|c|c|c|c|c|c|}
\hline & Rainfall & $\mathrm{H}^{+}$ & EC & $\mathrm{Cl}^{-}$ & $\mathrm{SO}_{4}{ }^{2-}$ & $\mathrm{NO}_{3}{ }^{-}$ & $\mathrm{Ca}^{2+}$ & $\mathrm{Mg}^{2+}$ & $\mathrm{Na}^{+}$ & $\mathrm{NH}_{4}{ }^{+}$ & $\mathrm{K}^{+}$ \\
\hline Rainfall & & 0.209 & $-0.783^{* * * *}$ & $-0.356 *$ & $-0.489 * * *$ & $-0.515^{* * *}$ & $-0.563^{* * * *}$ & $-0.387^{* *}$ & -0.135 & -0.208 & -0.077 \\
\hline $\mathrm{H}^{+}$ & 0.233 & & -0.215 & -0.096 & 0.027 & -0.148 & -0.32 & $-0.413^{* *}$ & -0.288 & -0.138 & -0.431 ** \\
\hline EC & $-0.847 * * * *$ & -0.285 & & $0.511^{* * *}$ & $0.665^{* * * *}$ & $0.499^{* * *}$ & $0.726^{* * * *}$ & $0.622^{* * * *}$ & 0.000 & 0.095 & 0.226 \\
\hline $\mathrm{Cl}^{-}$ & $-0.625 * * * *$ & -0.279 & $0.713^{* * * *}$ & & $0.676^{* * * *}$ & 0.288 & $0.602^{* * * * *}$ & $0.664^{* * * *}$ & $0.409 * *$ & 0.168 & 0.184 \\
\hline $\mathrm{SO}_{4}{ }^{2-}$ & $-0.777^{* * * *}$ & -0.137 & $0.870 * * * *$ & $0.746^{* * * *}$ & & 0.270 & $0.591^{* * * *}$ & $0.656^{* * * *}$ & 0.034 & -0.116 & 0.183 \\
\hline $\mathrm{NO}_{3}^{-}$ & $-0.642 * * * *$ & -0.115 & $0.779 * * * *$ & $0.689^{* * * *}$ & $0.801^{* * * *}$ & & $0.435^{* *}$ & $0.490^{* * *}$ & 0.074 & $0.346^{*}$ & -0.009 \\
\hline $\mathrm{Ca}^{2+}$ & $-0.687 * * * *$ & -0.270 & $0.714^{* * * *}$ & $0.492 * * *$ & $0.615^{* * * *}$ & $0.493 * * *$ & & $0.819 * * * *$ & 0.087 & 0.181 & $0.456^{* *}$ \\
\hline $\mathrm{Mg}^{2+}$ & $-0.740 * * * *$ & -0.188 & $0.814^{* * * *}$ & $0.636^{* * * *}$ & $0.682 * * * *$ & $0.526 * * *$ & $0.821 * * * *$ & & 0.126 & 0.094 & $0.422 * *$ \\
\hline $\mathrm{Na}^{+}$ & $-0.653 * * * *$ & -0.211 & $0.748^{* * * *}$ & $0.947 * * * *$ & $0.722 * * * *$ & $0.649 * * * * *$ & $0.559 * * * *$ & $0.717 * * * *$ & & 0.279 & 0.106 \\
\hline $\mathrm{NH}_{4}{ }^{+}$ & $-0.515 * * *$ & $-0.587^{* * * *}$ & $0.607 * * * *$ & 0.187 & 0.288 & $0.459 * *$ & $0.387^{* *}$ & 0.290 & 0.199 & & -0.381 * \\
\hline $\mathbf{K}^{+}$ & $-0.471^{* * *}$ & $-0.472 * *$ & $0.524 * * *$ & $0.378 * *$ & 0.365 * & 0.193 & $0.668^{* * * *}$ & $0.626^{* * * *}$ & 0.366 * & $0.553 * * * *$ & \\
\hline
\end{tabular}


Despite water loss due to the interception process, the average annual ion flux was higher under the canopy than in the open area in both stands. In Malik, the load was $229.6(185.3-270.0) \mathrm{kg} \cdot \mathrm{ha}^{-1} \cdot \mathrm{year}^{-1}$, whereas in Czarne, the load was $71.3(65.1-81.9) \mathrm{kg} \cdot \mathrm{ha}^{-1} \cdot \mathrm{year}^{-1}$. In both cases, these values exceeded the loads observed in the open area by a factor of two. The observed open area loads were 118.0 (98.8-158.1) kg.ha ${ }^{-1} \cdot \mathrm{year}^{-1}$ in Malik and 39.8 (35.2-47.2) $\mathrm{kg} \cdot \mathrm{ha}^{-1} \cdot \mathrm{year}^{-1}$ in Czarne.

The greatest differences in deposition between the studied stands were observed for $\mathrm{SO}_{4}{ }^{2-}, \mathrm{Ca}^{2+}$, $\mathrm{Mg}^{2+}$, and $\mathrm{NO}_{3}{ }^{-}$(Table 5). Throughfall loads of these elements at Malik exceeded those observed in the second stand, except for $\mathrm{NH}_{4}{ }^{+}$and $\mathrm{H}^{+}$, whose values in Czarne exceeded those recorded in Malik. Comparable loads were observed for $\mathrm{Na}^{+}$and $\mathrm{Cl}^{-}$in both stands.

Table 5. Total element deposition, deposition ratios, and enrichment ratios (ER)—averages for the research period calculated on the basis of annual data.

\begin{tabular}{|c|c|c|c|c|c|c|c|c|c|c|}
\hline $\begin{array}{l}\text { Sampling } \\
\text { Sites }\end{array}$ & $\mathrm{Cl}^{-}$ & $\mathrm{SO}_{4}{ }^{2-}$ & $\mathrm{NO}_{3}^{-}$ & $\mathrm{Ca}^{2+}$ & $\mathrm{Mg}^{2+}$ & $\mathrm{Na}^{+}$ & $\mathrm{NH}_{4}{ }^{+}$ & $\mathrm{K}^{+}$ & $\mathrm{H}^{+}$ & $\begin{array}{l}\text { Total } \\
\text { Load }\end{array}$ \\
\hline \multicolumn{11}{|c|}{ Bulk precipitation } \\
\hline \multicolumn{11}{|c|}{ Loads in $\mathrm{kg} \cdot \mathrm{ha}^{-1} \cdot$ year $^{-1}$} \\
\hline Czarne & 4.2 & 6.6 & 10.4 & 5.4 & 0.9 & 4.4 & 6.0 & 1.9 & 0.05 & 39.8 \\
\hline Malik & 14.4 & 42.3 & 19.0 & 22.7 & 4.5 & 8.4 & 3.8 & 2.9 & 0.06 & 118.0 \\
\hline \multicolumn{11}{|c|}{ Ratio loads (-) } \\
\hline Malik/Czarne & $\begin{array}{c}3.4 \\
(2.0-5.6)\end{array}$ & $\begin{array}{c}6.4 \\
(5.1-9.8)\end{array}$ & $\begin{array}{c}1.8 \\
(0.8-3.7)\end{array}$ & $\begin{array}{c}4.2 \\
(2.6-5.8)\end{array}$ & $\begin{array}{c}4.9 \\
(2.9-6.5)\end{array}$ & $\begin{array}{c}1.9 \\
(1.2-3.0)\end{array}$ & $\begin{array}{c}0.6 \\
(0.2-1.0)\end{array}$ & $\begin{array}{c}1.6 \\
(1.2-1.9)\end{array}$ & $\begin{array}{c}1.2 \\
(0.9-2.1)\end{array}$ & $\begin{array}{c}3.0 \\
(2.1-4.5)\end{array}$ \\
\hline \multicolumn{11}{|c|}{ Throughfall } \\
\hline \multicolumn{11}{|c|}{ Loads in $\mathrm{kg} \cdot \mathrm{ha}^{-1} \cdot$ year $^{-1}$} \\
\hline Czarne & 10.2 & 10.0 & 14.2 & 6.2 & 1.8 & 6.4 & 12.1 & 10.4 & 0.06 & 71.3 \\
\hline Malik & 13.4 & 71.0 & 70.9 & 36.4 & 5.8 & 6.7 & 5.1 & 20.3 & 0.01 & 229.6 \\
\hline \multicolumn{11}{|c|}{ Ratio loads (-) } \\
\hline Malik/Czarne & $\begin{array}{c}1.3 \\
(0.9-2.0)\end{array}$ & $\begin{array}{c}7.1 \\
(5.6-11.4)\end{array}$ & $\begin{array}{c}5.0 \\
(1.8-6.6)\end{array}$ & $\begin{array}{c}5.9 \\
(3.9-8.5)\end{array}$ & $\begin{array}{c}3.2 \\
(2.9-3.7)\end{array}$ & $\begin{array}{c}1.1 \\
(0.6-1.5)\end{array}$ & $\begin{array}{c}0.4 \\
(0.3-0.6)\end{array}$ & $\begin{array}{c}2.0 \\
(1.4-2.4)\end{array}$ & $\begin{array}{c}0.1 \\
(0.03-0.3)\end{array}$ & $\begin{array}{c}3.2 \\
(2.6-4.0)\end{array}$ \\
\hline \multicolumn{11}{|c|}{ Enrichment ratio (-) } \\
\hline Czarne & $\begin{array}{c}2.5^{* * *} \\
(2.2-2.9)\end{array}$ & $\begin{array}{c}1.5^{* * *} \\
(1.3-1.7)\end{array}$ & $\begin{array}{c}1.4^{*} \\
(1.3-1.4)\end{array}$ & $\begin{array}{c}1.1 \\
(0.8-1.5)\end{array}$ & $\begin{array}{c}2.0^{* * *} \\
(1.7-2.3)\end{array}$ & $\begin{array}{c}1.5^{* * *} \\
(1.3-1.8)\end{array}$ & $\begin{array}{c}2.0^{* * *} \\
(1.2-3.3)\end{array}$ & $\begin{array}{c}5.6^{* * *} \\
(4.4-7.6)\end{array}$ & $\begin{array}{c}1.2 \\
(0.8-1.6)\end{array}$ & $\begin{array}{l}1.8^{* * *} \\
(1.5-2.2)\end{array}$ \\
\hline Malik & $\begin{array}{c}0.9 \\
(0.5-1.7)\end{array}$ & $\begin{array}{c}1.7^{* *} \\
(0.9-2.9)\end{array}$ & $\begin{array}{l}3.7^{* * * *} \\
(2.3-9.4)\end{array}$ & $\begin{array}{c}1.6^{* *} \\
(1.1-2.0)\end{array}$ & $\begin{array}{c}1.3 * \\
(1.0-1.9)\end{array}$ & $\begin{array}{c}0.8 \\
(0.7-1.0)\end{array}$ & $\begin{array}{c}1.4 \\
(0.9-3.4)\end{array}$ & $\begin{array}{l}7.0^{* * *} \\
(5.8-8.8)\end{array}$ & $\begin{array}{l}0.1^{* * *} \\
(0.03-0.2)\end{array}$ & $\begin{array}{c}1.9^{* * *} \\
(1.3-2.6)\end{array}$ \\
\hline
\end{tabular}

In brackets the range for individual years is given. The significance of differences in the deposition in the open and under the canopy (Mann-Whitney $U$ test) at $\left.p<0.001\left(^{* * *}\right), p<0.01{ }^{(* *}\right)$, and $p<0.05\left(^{*}\right)$.

The highest ER values were recorded for $\mathrm{K}^{+}$, with an observed ER of 7.0 in Malik and 5.6 in Czarne. ER values were close to 1 for $\mathrm{Ca}^{2+}(1.1)$ and $\mathrm{H}^{+}(1.2)$ in Czarne, and $\mathrm{Cl}^{-}(0.9)$ and $\mathrm{Na}^{+}(0.8)$ in Malik. In the case of $\mathrm{H}^{+}$in Malik, the deposition under the canopy was an order of magnitude smaller compared to the open area (0.1) (Table 5). In both stands, the differences between deposition under the canopy and in the open area were statistically significant for most ions. The exceptions were $\mathrm{H}^{+}$and $\mathrm{Ca}^{2+}$ ions in Czarne and $\mathrm{Cl}^{-}, \mathrm{Na}^{+}$, and $\mathrm{NH}_{4}{ }^{+}$ions in Malik.

The average four-year flux of nitrogen $\left(\mathrm{N}_{-} \mathrm{NO}_{3}{ }^{-}+\mathrm{N}-\mathrm{NH}_{4}{ }^{+}\right)$in Malik was $20.0(10.9-25.3) \mathrm{kg} \cdot \mathrm{ha}^{-1}$ .year ${ }^{-1}, 80 \%$ of which was in the form of nitrogen nitrate. In Czarne, the total flux of nitrogen was $12.6(11.2-15.1) \mathrm{kg} \cdot \mathrm{ha}^{-1} \cdot \mathrm{year}^{-1}, 75 \%$ of which was in ammonium form. Nitrogen deposition under the canopy as compared to bulk participation was twice as high in Czarne and almost three times higher in Malik. In Malik, the nitrogen load exceeded critical values for coniferous stands, 3-15 kg.ha ${ }^{-1}$ .year $^{-1}$ [33], whereas in the case of Czarne, the value did not exceed this range.

In the Malik plot, the average annual flux of $\mathrm{K}^{+}$from throughfall reached $20.3 \mathrm{~kg} \cdot \mathrm{ha}^{-1}$, of which $85.8 \%\left(17.4 \mathrm{~kg} \cdot \mathrm{ha}^{-1} \cdot \mathrm{year}^{-1}\right)$ was the effect of leaching. In the Czarne plot, the total annual average 
$\mathrm{K}^{+}$deposition under the canopy was $10.4 \mathrm{~kg} \cdot \mathrm{ha}^{-1} \cdot \mathrm{year}^{-1}$, of which leaching accounted for $73.8 \%$ $\left(7.7 \mathrm{~kg} \cdot \mathrm{ha}^{-1 \cdot}\right.$ year $\left.^{-1}\right)$. In both stands, the highest $\mathrm{K}^{+}$loads were observed between May and October and, in the Malik plot, also in November and December (Figure 5).

(a)

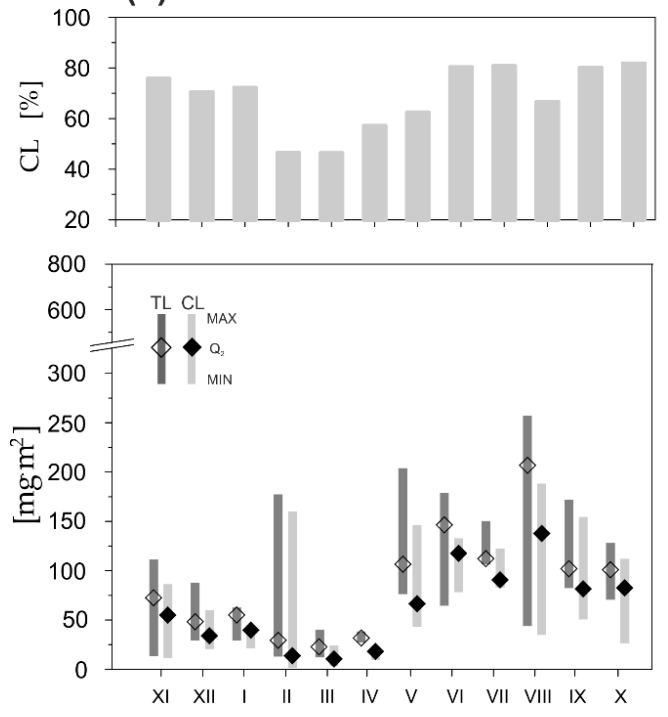

(b)
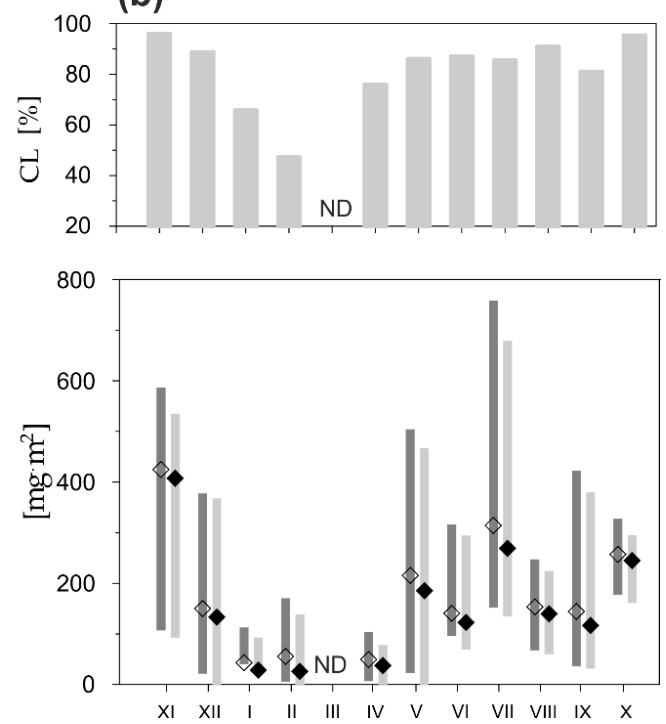

Figure 5. Distribution of total $\mathrm{K}^{+}$load (TL), load leached from the canopy (CL), and load leached from the canopy as a percentage of total $\mathrm{K}^{+}$deposition in Czarne (a) and in Malik (b). ND—no data, $\mathrm{Q}_{2}-$ median.

These months between May and October were also the period when canopy leaching made the greatest contribution to total deposition to the forest floor. In Czarne, the total $\mathrm{Ca}^{2+}$ load observed at the forest floor was related to the atmospheric inflow rather than leaching processes. In Malik, the contribution of these processes to total $\mathrm{Ca}^{2+}$ deposition $\left(36.4 \mathrm{~kg} \cdot \mathrm{ha}^{-1} \cdot\right.$ year $\left.^{-1}\right)$ reached $37.7 \%$ $\left(13.7 \mathrm{~kg} \cdot \mathrm{ha}^{-1} \cdot\right.$ year $\left.^{-1}\right)$. In addition to $\mathrm{K}^{+}$and $\mathrm{Ca}^{2+}$, canopy leaching was also an important source of $\mathrm{Mg}^{2+}$ in throughfall. Significant canopy leaching of $\mathrm{Mg}^{2+}$ was observed both in Malik, where it reached $23.1 \%\left(1.3 \mathrm{~kg} \cdot \mathrm{ha}^{-1} \cdot \mathrm{year}^{-1}\right)$, and Czarne, where it accounted for $26.0 \%\left(0.5 \mathrm{~kg} \cdot \mathrm{ha}^{-1} \cdot \mathrm{year}^{-1}\right)$ of the throughfall.

To evaluate the fractions of the measured ions, which did not play any role in determining the acidity/alkalinity of the bulk precipitation, the non-sea salt (nss) fraction ion concentrations of $\mathrm{Ca}^{2+}$, $\mathrm{K}^{+}, \mathrm{Mg}^{2+}$, and $\mathrm{SO}_{4}{ }^{2-}$ were calculated. Results showed that the nss fraction ion concentrations were 16.5, 4.4, 38.0, and $6.3 \mu \mathrm{eq} \cdot \mathrm{dm}^{-3}$ (Czarne), and 146.1, 47.7, 196.3, and $11.4 \mu \mathrm{eq} \cdot \mathrm{dm}^{-3}$ (Malik) for $\mathrm{SO}_{4}{ }^{2-}$, $\mathrm{Mg}^{2+}, \mathrm{Ca}^{2+}$, and $\mathrm{K}^{+}$, respectively. The percent contribution of the non-marine source amounted to $82.9 \%, 41.7 \%, 96.9 \%$, and $91.2 \%$ (Czarne), and $94.8 \%, 76.6 \%, 98.6 \%$, and $89.0 \%$ (Malik) for $\mathrm{SO}_{4}{ }^{2-}, \mathrm{Mg}^{2+}$, $\mathrm{Ca}^{2+}$, and $\mathrm{K}+$, respectively.

In the Czarne plot, the $\mathrm{NO}_{3}{ }^{-} / \mathrm{nsSO}_{4}{ }^{2-}$ ratio in the bulk precipitation indicated the dominant role of nitrogen compounds in acidification processes (1.47). In Malik, a marked dominance of sulfur compounds was observed $\left(\mathrm{NO}_{3}{ }^{-} / \mathrm{nssSO}_{4}{ }^{2-}=0.37\right)$. The fractional acidity (FA) indicator calculated for bulk precipitation confirmed that $83 \%$ (Czarne) and $95 \%$ (Malik) of acidifying compounds were neutralized. In the case of Czarne, neutralization was associated with the presence of $\mathrm{NH}_{4}{ }^{+}\left(\mathrm{NF}_{\mathrm{NH}}\right.$ $=0.94)$ and $\mathrm{Ca}^{2+}\left(\mathrm{NF}_{\mathrm{Ca}}=0.93\right)$, whereas $\mathrm{Mg}^{2+}\left(\mathrm{NF}_{\mathrm{Mg}}=0.11\right)$ and $\mathrm{K}^{+}\left(\mathrm{NF}_{\mathrm{K}}=0.15\right)$ had marginal effects. The ions determining neutralization at Malik were $\mathrm{Ca}^{2+}\left(\mathrm{NF}_{\mathrm{Ca}}=0.98\right)$ and $\mathrm{Mg}^{2+}\left(\mathrm{NF}_{\mathrm{Mg}}=0.24\right)$, whereas $\mathrm{NH}_{4}{ }^{+}\left(\mathrm{NF}_{\mathrm{NH} 4}=0.18\right)$ and $\mathrm{K}^{+}\left(\mathrm{NF}_{\mathrm{K}}=0.06\right)$ had significantly lower impacts. 


\subsection{Source of Ionic Species}

For each plot, three or four complementary components were distinguished using the concentrations of ions in bulk precipitation and throughfall (Table 6). For bulk precipitation, they explained $81 \%$ (Malik) and $76 \%$ (Czarne) of the total variance in the chemical composition of rainfall. For throughfall, the components explained $84 \%$ of the total variance for Malik and $89 \%$ for Czarne. On the basis of the results obtained from the Malik plot, the PC1 component represented the effect of local pollution on the chemical composition of bulk precipitation and throughfall. This component was correlated with base variables such as $\mathrm{Cl}^{-}, \mathrm{SO}_{4}{ }^{2-}, \mathrm{Ca}^{2+}$, and $\mathrm{Mg}^{2+}$ (Table 6). The effect of pollution was also apparent in Czarne, where it was represented by the main factor PC2 (bulk precipitation) and $\mathrm{PC} 1$ (throughfall). These factors included $\mathrm{SO}_{4}{ }^{2-}, \mathrm{NO}_{3}{ }^{-}, \mathrm{NH}_{4}{ }^{+}$, and $\mathrm{Ca}^{2+}$ (only bulk precipitation).

Table 6. Factor loading and explained variance for bulk precipitation (BP) and throughfall (TF).

\begin{tabular}{|c|c|c|c|c|c|c|c|c|}
\hline \multirow{3}{*}{ Solute/Factor } & \multicolumn{8}{|c|}{ Bulk Precipitation } \\
\hline & \multicolumn{4}{|c|}{ Malik } & \multicolumn{4}{|c|}{ Czarne } \\
\hline & PC1 & PC2 & PC3 & PC4 & PC1 & PC2 & PC3 & \\
\hline $\mathrm{Cl}^{-}$ & 0.84 & 0.23 & 0.11 & 0.08 & 0.17 & 0.91 & -0.02 & \\
\hline $\mathrm{NO}_{3}^{-}$ & 0.14 & 0.09 & 0.92 & 0.05 & 0.73 & 0.47 & 0.14 & \\
\hline $\mathrm{SO}_{4}^{2-}$ & 0.85 & 0.03 & 0.36 & -0.02 & 0.63 & 0.49 & 0.26 & \\
\hline $\mathrm{Na}^{+}$ & 0.28 & -0.22 & 0.18 & 0.82 & 0.27 & 0.85 & 0.14 & \\
\hline $\mathrm{K}^{+}$ & 0.34 & 0.75 & -0.05 & -0.08 & 0.12 & 0.45 & 0.70 & \\
\hline $\mathrm{Mg}^{2+}$ & 0.85 & 0.15 & -0.21 & 0.12 & 0.52 & 0.39 & 0.33 & \\
\hline $\mathrm{Ca}^{2+}$ & 0.89 & -0.12 & 0.19 & -0.02 & 0.89 & 0.03 & -0.08 & \\
\hline $\mathrm{NH}_{4}{ }^{+}$ & 0.56 & -0.12 & 0.30 & -0.64 & 0.77 & 0.22 & 0.45 & \\
\hline $\mathrm{H}^{+}$ & -0.12 & 0.86 & 0.14 & -0.07 & -0.11 & 0.11 & -0.87 & \\
\hline Eigenvalues & 3.73 & 1.52 & 1.05 & 1.00 & 4.59 & 1.20 & 1.06 & \\
\hline Explained variance (\%) & 39 & 16 & 14 & 12 & 30 & 27 & 19 & \\
\hline $\begin{array}{c}\text { Cumulative explained } \\
\text { variance }(\%)\end{array}$ & 39 & 55 & 69 & 81 & 30 & 57 & 76 & \\
\hline \multirow{3}{*}{ Solute/Factor } & \multicolumn{8}{|c|}{ Throughfall } \\
\hline & \multicolumn{4}{|c|}{ Malik } & \multicolumn{4}{|c|}{ Czarne } \\
\hline & PC1 & PC2 & PC3 & PC4 & PC1 & PC2 & PC3 & PC4 \\
\hline $\mathrm{Cl}^{-}$ & 0.91 & 0.10 & 0.18 & -0.07 & 0.27 & 0.91 & 0.19 & 0.13 \\
\hline $\mathrm{NO}_{3}^{-}$ & 0.24 & 0.82 & 0.01 & 0.10 & 0.92 & 0.31 & 0.15 & 0.03 \\
\hline $\mathrm{SO}_{4}^{2-}$ & 0.91 & -0.09 & 0.00 & 0.10 & 0.76 & 0.49 & 0.16 & -0.03 \\
\hline $\mathrm{Na}^{+}$ & 0.01 & 0.80 & 0.08 & -0.18 & 0.26 & 0.91 & 0.25 & 0.08 \\
\hline $\mathrm{K}^{+}$ & 0.44 & 0.13 & -0.70 & -0.30 & -0.13 & 0.28 & 0.60 & 0.58 \\
\hline $\mathrm{Mg}^{2+}$ & 0.82 & 0.27 & -0.29 & -0.24 & 0.20 & 0.38 & 0.83 & -0.07 \\
\hline $\mathrm{Ca}^{2+}$ & 0.83 & 0.34 & -0.09 & -0.13 & 0.31 & 0.08 & 0.84 & 0.07 \\
\hline $\mathrm{NH}_{4}^{+}$ & 0.18 & 0.18 & 0.90 & -0.13 & 0.76 & 0.04 & 0.33 & 0.47 \\
\hline $\mathrm{H}^{+}$ & -0.08 & -0.05 & 0.01 & 0.96 & -0.15 & -0.05 & 0.04 & -0.93 \\
\hline Eigenvalues & 3.80 & 1.51 & 1.28 & 0.95 & 4.60 & 1.32 & 1.15 & 0.92 \\
\hline Explained variance (\%) & 37 & 18 & 16 & 13 & 26 & 25 & 22 & 16 \\
\hline $\begin{array}{c}\text { Cumulative explained } \\
\text { variance }(\%)\end{array}$ & 37 & 55 & 71 & 84 & 26 & 50 & 73 & 89 \\
\hline
\end{tabular}

Boldfaced values are strong $(>0.70$ or $<-0.70)$ loadings; values in italics are moderate loadings.

For Czarne, PC2 components for bulk precipitation and throughfall were identified, which were correlated with concentrations of $\mathrm{Cl}^{-}, \mathrm{Na}^{+}$, and to a lesser extent with $\mathrm{Mg}^{2+}$ concentrations. These components represented the effect of marine aerosol precipitation on chemical composition. In the case of Malik, this component was not distinguished. In both plots, we identified a component associated with $\mathrm{H}^{+}$but not with $\mathrm{NO}_{3}{ }^{-}$or $\mathrm{SO}_{4}{ }^{2-}$. In Czarne, $\mathrm{NH}_{4}{ }^{+}$had a high contribution to the 
formation of this component, but this dependence was of a different nature. Unlike for $\mathrm{H}^{+}$ions, the load had a positive mark (Table 6). In the matrix of factor loads, the PC 3 component for Malik throughfall was noteworthy, as it was positively correlated with $\mathrm{K}^{+}$concentrations and negatively correlated with $\mathrm{NH}_{4}{ }^{+}$(Figure 6).
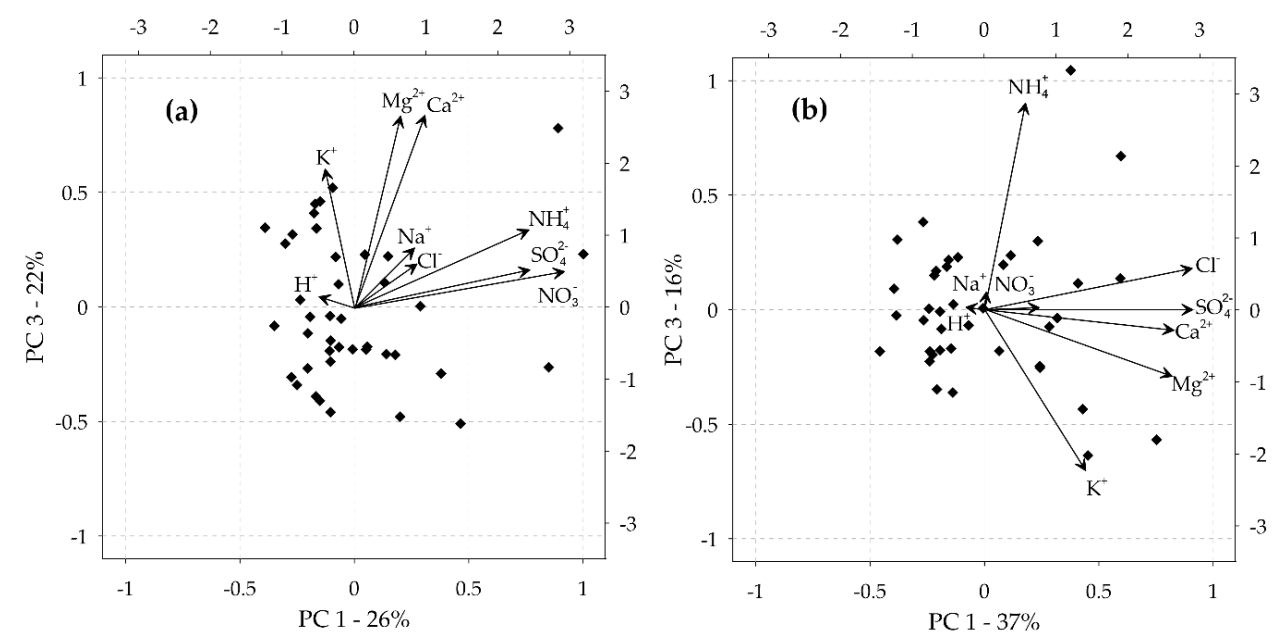

Figure 6. Diagram (biplot) based on the principal component analysis (PCA) for throughfall in Czarne (a) and in Malik (b).

This component can be associated with the presence of $\mathrm{K}^{+}$leaching processes from plants. For Czarne, no main component that would clearly indicate the leaching processes was identified. $\mathrm{K}^{+}$contributed to the creation of two components: PC3 and PC4. In the PC3 component, high load values characterized $\mathrm{Mg}^{2+}$ and $\mathrm{Ca}^{2+}$, whose presence in throughfall in the Czarne plot was primarily associated with atmospheric inflow. In the pine stand in $\mathrm{Czarne}$, no $\mathrm{Ca}^{2+}$ leaching processes were observed. In addition to the PC 3 component, $\mathrm{K}^{+}$ions contributed to PC4 component formation, which was correlated primarily with $\mathrm{H}^{+}$and to a lesser extent $\mathrm{NH}_{4}{ }^{+}$.

\section{Discussion}

Interception, understood as the part of precipitation retained by the canopy, is an important element of water balance in forest ecosystems. During the study period, there were no significant differences in the amount of precipitation that reached the soil in the two observed stands. The parameter that differentiates these areas is the variation scale for interception. In the forest stand at Malik, located in a mountainous area with an elevation of up to $300 \mathrm{~m}$ above sea level, there were cases when interception was negative. Additional water inflow comes from fog deposition. This process is particularly effective in conifer stands, which have a larger reception area that facilitates the intake of water from fog $[1,6,34]$.

Despite the loss of water in the interception process, we observed deposition of more than twice the values observed outside the forest in both stands. This difference can be explained by the effect of canopy leaching and the wash-off of aerosols that accumulate on tree surfaces through dry deposition $[6,10,14,17,35-37]$.

In both plots, the highest load increase was recorded for $\mathrm{K}^{+}$ions: 5.6 in Czarne and 7.0 in Malik. These results are consistent with previous research [6,8,37-39] carried out both in coniferous and deciduous stands. The research conducted by Kowalska et al. [11] on stands of diverse species in Poland confirmed the enrichment of throughfall with $\mathrm{K}^{+}$at the level of 4.4 (pine), 4.7 (spruce), 7.2 (beech), and 11.5 (oak). The leaching process is primarily related to monovalent $\mathrm{K}^{+}$ions [20,21] due to greater mobility and weaker bonding in cell walls, chloroplasts, and enzymes compared to divalent ions $[22,40]$. The intensity of $\mathrm{K}^{+}$leaching depends on many factors, including the type and age of the stand [6,14,17], canopy [10,12], distance from the edge of the forest [41], and inflow of acidifying compounds from the atmosphere $[6,14,18,26]$. 
On the basis of the canopy budget model, we found that, in the case of total potassium deposition on the forest floor, $85.8 \%$ in Malik and $73.8 \%$ in Czarne came from canopy leaching processes. These values are comparable with the results of other authors. Draaijers et al. [26], Rothe et al. [42], and Kozłowski et al. [14] noted the contribution of leaching processes for spruce stands at levels of $89 \%, 80 \%$, and $98.7 \%$, respectively. For pine stands, Hermann et al. [10] reported values in the $44 \%-71 \%$ range.

The analysis of leaching intensity on the scale of the hydrological year indicates the occurrence of seasonal variation. In both stands, the maximum leaching values were recorded in the growing season, with the maximum falling between May and November. As Fober [43] reports, the contents of elements in plant tissues are subject to strong seasonal changes. According to Le Taconm and Toutain [44] and Kozłowski et al. [14], $\mathrm{K}^{+}$concentration in assimilation organs clearly decreases in the period from September to October, and increases in the summer months.

These observations are in line with the results of Kozłowski et al. [14] in a study of fir and spruce stands, where the maximum values of $\mathrm{K}^{+}$ions from leaching were found at the beginning and the end of the growing season. Moreover, Adriaenssens et al. [8] reported that the highest leaching intensity occurs during the growing season.

For both stands, air pollution was an important factor affecting throughfall's physicochemical properties and chemical composition. In Malik, the most important source of pollution is the cement and lime industry and the related local emission of dust pollution. Accordingly, the loads of $\mathrm{SO}_{4}{ }^{2-}$ and $\mathrm{Ca}^{2+}$ recorded in Malik exceeded the values observed in the other stand by more than seven and six times, respectively. $\mathrm{Ca}^{2+}, \mathrm{SO}_{4}{ }^{2-}$, and $\mathrm{Cl}^{-}$present in throughfall at Malik are correlated with $\mathrm{PC}$, which represents an anthropogenic factor. Photographs of two-year-old pine needles from this area, taken with a scanning electron microscope, revealed incrustations near the stomata resulting from dust deposition. A point analysis of chemical composition conducted with an ED-XRF microanalyzer found sulfur and calcium in significant quantities in the samples whose tissue was nearest to the stoma [1]. Under favorable conditions, the process of gypsum formation takes place [1], which leads to partial clogging of the stoma [45] and may result in the deterioration of the stand's health and the increased leaching of biogenic elements.

In Czarne, the anthropogenic factor was represented by the PC1 and encompassed the concentrations of $\mathrm{NH}_{4}{ }^{+}, \mathrm{NO}_{3}{ }^{-}$, and $\mathrm{SO}_{4}{ }^{2-}$. The presence of these ions in throughfall should be considered alongside the wash-off of substances deposited on the surface of plants $[10,36,46]$.

The $\mathrm{NO}_{3}{ }^{-}$and $\mathrm{SO}_{4}{ }^{2-}$ loads found in bulk deposition in the Czarne plot came from long-distance transport, as there were no local emitters in Czarne. Deposition of $\mathrm{NH}_{4}{ }^{+}$, on the other hand, depends mainly on agricultural activities, as Rodrigo et al. [20] observed in Mediterranean forests, Huber and Kreutzer [47] in Germany, Neirynck et al. [48] in a Scots pine forest in northern Belgium, Shen et al. [46] in two plantation forests in southeast China, and Cao et al. [49] in a cool-temperate deciduous broad-leaved forest (Japan).

Nitrogen is an element that differentiated the examined stands. In Malik, $\mathrm{N}-\mathrm{NO}_{3}$ accounted for $80 \%$ of the total nitrogen, whereas in Czarne, this figure was only $25 \%$. The average annual load of $\mathrm{NO}_{3}{ }^{-}$in the stand at Malik was almost five times greater than in the Czarne stand. The source of $\mathrm{NO}_{3}{ }^{-}$ in the throughfall at Malik, apart from the production of cement, are emissions associated with the S7 expressway located near the stand. The specific composition of the rainwater penetrating through the stand in Malik is a result of wash-off of alkaline dust, derived from the so-called White Basin cement and lime works, deposited on the surfaces of trees.

Sea aerosols represent an important factor that affects ion concentration in precipitation in Czarne, as they are an important source of $\mathrm{Cl}^{-}$and $\mathrm{Na}^{+}$ions, and, to a lesser extent, $\mathrm{Mg}^{2+}$ and $\mathrm{SO}_{4}{ }^{2}$ ions. The studied area is located approximately $100 \mathrm{~km}$ south of the Baltic Sea coast. For Czarne, there were statistically significant dependencies between $\mathrm{Cl}^{-}$and $\mathrm{Na}^{+}$distributions. For Malik, the analogous dependence turned out to be less statistically significant $(p<0.01)$. This was confirmed by the results of the PCA for the Malik plot, as $\mathrm{Cl}^{-}$ions were correlated with PC1, representing anthropogenic impact, 
but there was no correlation with $\mathrm{Na}^{+}$ions. In the second plot, both $\mathrm{Cl}^{-}$and $\mathrm{Na}^{+}$were correlated with PC2, representing sea aerosols. The probable source of the high load of chlorides in the precipitation at Malik is dust emitted from two cement plants. According to [4], 800.4 Mg of cement dust was emitted from 2010 to 2013 in the area of Malik. Seo et al. [50] indicate that cement kiln dust (CKD) is a major by-product of cement manufacturing. In general, the maximum chloride content of cement is $0.10 \%$, whereas the chloride contained in CKD may reach 0.25-15.4 wt \% [51]. CKD consists of a set of oxidized, anhydrous phases, which include oxides, aluminosilicates, sulphates, and chlorides. Many of these phases, including calcium oxide $(\mathrm{CaO})$, arcanite $\left(\mathrm{K}_{2} \mathrm{SO}_{4}\right)$, and sylvine $(\mathrm{KCl})$, are unstable or highly soluble. After the contact of dust with water, these phases can completely dissolve, followed by the precipitation of more or less stable phases [52]. As reported by Uliasz-Bocheńczuk [53], dust leachates from electrostatic precipitators are characterized by high concentrations of chlorides.

It is widely known that coniferous stands contribute to the increased acidity of rainwater $[6,11,14,36,54]$. The presence of cement/lime dust in the Malik plot caused the $\mathrm{pH}$ of precipitation penetrating through the canopy to increase by almost $1 \mathrm{pH}$ unit as compared to bulk precipitation. The location of the Malik area at a distance of 2.5 to $21.0 \mathrm{~km}$ from the emission sources causes a periodic strong effect of cement and lime plants on this stand. The observed alkalization of precipitation after passing through the crown zone is conditioned by dry deposition of the cement and lime dust emitted by nearby industrial plants on the surface of the assimilation organs. This dust, characterized by high $\mathrm{pH}$, is washed off the plant surface and deposited into the soil when precipitation occurs [3,4]. Research by Ots and Mandre [55] showed that deposition volume depends on the distance from the source of emission and the direction of the wind.

Neutralization ratios of acidifying compounds confirmed a significant contribution of ammonium nitrogen in the Czarne plot. For the Czarne plot, the basic factors influencing the chemical composition of precipitation are the lack of local industrial emitters, the local emission of agricultural pollutants, the inflow of pollutants to the study area, and its location near the sea. This was confirmed by low precipitation mineralization that was close to the background value, as well as a clear upward trend in $\mathrm{pH}$ observed in recent years, which is associated with the reduction of $\mathrm{SO}_{2}$ concentrations in the atmosphere [5]. In this situation, the chemical composition of sub-crown precipitation is determined by the processes of ion leaching from assimilation organs $\left(\mathrm{K}^{+}\right.$and $\left.\mathrm{Mg}^{2+}\right)$, the presence of agricultural pollutants $\left(\mathrm{NH}_{4}^{+}\right)$, and the inflow of marine aerosols $\left(\mathrm{Na}^{+}\right.$and $\left.\mathrm{Cl}^{-}\right)$.

These values are similar to those obtained by Golobočanin et al. [56] in Central Serbia. In the case of the $\mathrm{NF}_{\mathrm{Ca}}$ ratio, the higher values recorded on the Malik plot clearly indicate that calcium from the cement and lime industry has a significant effect on the natural environment of this area.

\section{Conclusions}

This study allowed us to verify the hypothesis formulated at the beginning of the manuscript. It was found that:

- $\quad$ The presence of cement/lime dust, mainly calcium and magnesium, emitted by industrial plants on Malik plot, affects conductivity, $\mathrm{pH}$, and the chemical composition of precipitation, playing a key role in the neutralization processes of acidogenic compounds.

- Emissions from agricultural areas, mainly with ammonium ions, as well as chlorides and sodium, which are the source of marine aerosols, affected a low level of conductivity of atmospheric precipitation and the precipitation's composition on Czarne plot, playing a key role in the neutralization processes of acidogenic compounds.

- Regardless of air pollution, the intensity of quantitative and qualitative transformation of precipitation in both pine stands was comparable. In both cases, the total ion load in throughfall was twice as high as on the open area, with the highest leaching intensity in the growing season. The leaching processes of $\mathrm{K}^{+}$and $\mathrm{Mg}^{2+}$ did not depend on various anthropogenic pressures. 
Author Contributions: R.K. (Rafał Kozłowski) and R.K. (Robert Kruszyk) were involved in the sampling, designing of the study, experiments, development of the chemical analysis, and writing the manuscript. S.M. wrote the manuscript. All authors read and approved the final manuscript.

Funding: This research was funded by the Jan Kochanowski University, Adam Mickiewicz University and University of Agriculture in Kraków.

Conflicts of Interest: The authors declare no conflict of interest.

\section{References}

1. Kozłowski, R. The functioning of selected Polish geoecosystems under diverse anthropopressure conditions-The case of low mountains and foothills. Landf. Anal. 2013, 23, 1-150.

2. Swiercz, A. Chemical transformations in podzolic soils inducted by alkaline and acidic emissions in the Świętokrzyski region of Poland. Pol. J. Environ. Stud. 2008, 17, 129-138.

3. Kozłowski, R.; Szwed, M. Utilisation of bio- and geoindicators for assessment of the state of natural environment in the south-western part of the Świętokrzyskie Mountains. In Infrastructure and Environment; Krakowiak-Bal, A., Vaverkova, M., Eds.; Springer: Cham, Germany, 2019. [CrossRef]

4. Kozłowski, R.; Szwed, M.; Żukowski, W. Pine needles as bioindicator of pollution by trace elements from cement-limestone industry in Central-Eastern Poland. Carpathian J. Earth Environ. Sci. 2019, 14, 541-549. [CrossRef]

5. Szpikowski, J.; Szpikowska, G.; Domańska, M.; Kruszyk, R.; Majewski, M. Condition and change of the environment geoekosystem of the upper Parsęta catchment. In the State and Changes of the Natural Environment of Polish Geoecosystems in the Years 1994-2015 Based on the Implementation of the Integrated Monitoring Natural Environment; Kostrzewski, A., Majewski, M., Eds.; Biblioteka Monitoringu Środowiska: Warsaw, Poland, 2018; pp. 75-124.

6. Małek, S. Nutrient fluxes in planted Norway Spruce stands of different age in Southern Poland. Water Air Soil Pollut. 2010, 209, 45-59. [CrossRef]

7. Kozłowski, R.; Jóźwiak, M. The transformation of precipitation in the tree canopy in selected forest ecosystems of Poland's Świętokrzyskie Mountains. Prz. Geogr. 2017, 89, 133-153. [CrossRef]

8. $\quad$ Adriaenssens, S.; Hansen, K.; Staelens, J.; Wuyts, K. Throughfall deposition and canopy exchange processes along a vertical gradient within the canopy of beech (Fagus sylvatica L.) and Norway spruce (Picea abies (L.) Karst). Sci. Total Environ. 2012, 420, 168-182. [CrossRef]

9. Adriaenssens, S.; Staelens, J.; Wuyts, K.; De Schrijver, A.; Van Wittenberghe, S.; Wuytack, T.; Kardel, F.; Verheyen, K.; Samson, R.; Boeckx, P. Foliar nitrogen uptake from wet deposition and the relation with leaf wettability and water storage capacity. Water Air Soil Pollut. 2011, 219, 43-57. [CrossRef]

10. Herrmann, M.; Pust, J.; Pott, R. The chemical composition of throughfall beneath oak, birch and pine canopies in Northwest Germany. Plant Ecol. 2006, 184, 273-285. [CrossRef]

11. Kowalska, A.; Astel, A.; Boczoń, A.; Polkowska, Ż. Atmospheric deposition in coniferous and deciduous tree stands in Poland. Atmos. Environ. 2016, 133, 145-155. [CrossRef]

12. Whelan, M.J.; Sanger, L.J.; Baker, M.; Anderson, J.M. Spatial patterns of throughfall and mineral ion deposition in a lowland Norway spruce (Picea abies) plantation at the plot scale. Atmos. Environ. 1998, 32, 3493-3501. [CrossRef]

13. Kozłowski, R.; Jóźwiak, M. Chemical denudation in a geoekosystem in acid immision conditions. Ecol. Chem. Eng. S. 2013, 20, 41-54. [CrossRef]

14. Kozłowski, R.; Jóźwiak, M.; Jóźwiak, M.; Bochenek., W. Assessment of $\mathrm{K}^{+}, \mathrm{Ca}^{2+}$ and $\mathrm{Mg}^{2+}$ volume leaching in selected tree stands under conditions of acidic deposition. Sylwan 2012, 156, 607-615. [CrossRef]

15. Kruszyk, R.; Kostrzewski, A.; Tylkowski, J. Variability of throughfall and stemflow deposition in pine and beech stands (Czarne Lake catchment, Gardno Lake catchment on Wolin Island). Prace Geogr. 2015, 143, 85-102. [CrossRef]

16. Kruszyk, R. Changes in the physical properties of precipitation in pine stands in the area with a low degree of air pollution (Western Pomerania). Quaest. Geogr. 2013, 32, 27-37. [CrossRef]

17. Małek, S.; Astel, A. Throughfall chemistry in a spruce chronosequence in southern Poland. Environ. Pollut. 2008, 155, 517-527. [CrossRef] 
18. Polkowska, Ż.; Astel, A.; Walna, B.; Małek, S.; Mędrzycka, K.; Górski, T.; Siepak, J.; Namieśnik, J. Chemometric analysis of rainwater and throughfall at several sites in Poland. Atmos. Environ. 2005, 39, 837-855. [CrossRef]

19. Potter, C.S.; Ragsdale, H.L.; Swank, W.T. Atmospheric Deposition and Foliar Leaching in a Regenerating Southern Appalachian Forest Canopy. J. Ecol. 1991, 79, 97-115. [CrossRef]

20. Rodrigo, A.; Àvila, A.; Rodà, F. The chemistry of precipitation, throughfall and stemflow in two holm oak (Quercus ilex L.) forests under a contrasted pollution environment in NE Spain. Sci. Total Environ. 2003, 305, 195-205. [CrossRef]

21. Ukonmaanaho, L.; Starr, M. Major nutrients and acidity: Budgets and trends at four remote boreal stands in Finland dyring the 1990s. Sci. Total. Environ. 2002, 297, 21-41. [CrossRef]

22. Marschner, H. Mineral Nutrition of Higher Plants; Academic Press: London, UK, 1995. [CrossRef]

23. Soil Taxonomy. A Basic System of Soil Classification for Making and Interpreting Soil Surveys. In Agriculture Handbook, 2nd ed.; United States Department of Agriculture, Natural Resources Conservation Service: Washington, DC, USA, 1999; Volume 436, pp. 1-886.

24. World References Base for Soil Resources 2006. A Framework for International Classification, Correlation and Communication; World Soil Resources Reports 103; Food and Agriculture Organization of the United Nations: Roma, Italy, 2006; pp. 1-145.

25. Bredemeier, M. Forest canopy transformation of atmospheric deposition. Water Air Soil Pollut. 1988, 40, 121-138. [CrossRef]

26. Draaijers, G.P.J.; Erisman, J.W.; van Leuven, N.F.M.; Romer, F.G.; Te Win kel, B.H.; Veltkamp, A.C.; Vermeulen, A.T.; Wyers, G.P. The impact of canopy exchange on differences observed between atmospheric deposition and throughfall fluxes. Atmos. Environ. 1997, 31, 387-397. [CrossRef]

27. Ulrich, B. Interaction of forest canopies with atmospheric constit uents: $1983 \mathrm{SO}_{2}$, alkali and earth alkali cations and chloride. In Effect of Accumulation of Air Pollutants in Forest Ecosystems; Ul rich, B., Pankrath, J., Eds.; Reidel Publishing Company: Dordrecht, The Netherlands, 1983; pp. 33-45. [CrossRef]

28. Van der Mass, M.P.; Pape, T. Hydrochemistry of two Douglas fir ecosystems and a heather ecosystem in the Veluwe, the Netherlands. In Dutch Priority Programme on Acidification Rep.120.1.01; National Institute of Public Health and Environmental Protection: Bilthoven, NL, USA, 1991.

29. Keene, W.C.; Pszenny, A.P.; Galloway, J.N.; Hawley, M.E. Sea salt correction and interpretation of constituent ratios in marine precipitation. J. Geophys. Res. 1986, 91, 6647-6658. [CrossRef]

30. Kulshrestha, U.C.; Kulshrestha, J.M.; Sekar, R.; Sastry, G.S.R.; Vairamani, M. Chemical characteristics of rain water at an urban site of south-central India. Atmos. Environ. 2003, 37, 3019-3026. [CrossRef]

31. Parashar, D.C.; Granat, L.; Kulshrestha, U.C.; Pillai, A.G.; Naik, M.S.; Momin, G.A.; Prakasa, R.P.S.; Safai, P.D.; Khemani, L.T.; Naqvi, S.W.A.; et al. Chemical composition of precipitation in India and Nepal. In A Preliminary Report on an Indo-Swedish Project on Atmospheric Chemistry; Department of Meteorology, Stockholm University, International Meteorological Institute, Stockholm University, International Meteorological Institute: Stockholm, Sweden, 1996.

32. Balasubramanian, R.; Victor, T.; Chun, N. Chemical and statistical analysis of precipitation in Singapore. Water Air Soil Pollut. 2001, 130, 451-456. [CrossRef]

33. Nilsson, J.; Grennfelt, P. Critical Loads for Sulphur and Nitrogen; Report from the Nordic Working Group; Nordic Council of Ministers: Copenhagen, Denmark, 1988; p. 417.

34. Błaś, M.; Sobik, M.; Quiel, F.; Netzel, P. Temporal and spatial variations of fog in the Western Sudety Mts., Poland. Atmos. Res. 2002, 64, 19-28. [CrossRef]

35. Likens, G.E.; Bormann, F.H. Biogeochemistry of a Forested Ecosystem; Springer: New York, NY, USA, 1995. [CrossRef]

36. Žaltauskaite, J.; Juknys, R. Comparisation of principal ion fluxes and their modifications in the forest stands of different tree species. Balt. For. 2011, 17, 179-188.

37. Caggiano, R.; Fikova, R.; Trippetta, S.; Bratanova-Doncheva, S.; Ignatova, N.; Telesca, L. An assessment of rainfall modification in mountainous ecosystems dominated by Fagus sylvatica L. and Picea abies (L.) Karst. (Western Balkans, Bulgaria) by multivariate analyses. Eur. J. For. Res. 2014, 133, 699-711. [CrossRef]

38. Balestrini, R.; Arisci, S.; Bizio, M.C.; Mosello, R.; Rogora, M.; Tagliaferri, A. Dry deposition of particles and canopy exchange: Comparison of wet, bulk and throughfall deposition at five forest sites in Italy. Atmos. Environ. 2007, 41, 745-756. [CrossRef] 
39. De Schrijver, A.; Geudens, G.; Augusto, L.; Staelens, J.; Mertens, J.; Wuyts, K.; Gielis, L.; Verheyen, K. Effects of vegetation type on throughfall deposition and seepage flux: A review. Oecologia 2007, 153, 663-674. [CrossRef]

40. Staelens, J.; De Schrijver, A.; Verheyen, K. Seasonal variation in throughfall and stemflow chemistry beneath a European beech (Fagus sylvatica) tree in relation to canopy phenology. Can. J. For. Res. 2007, 37, 1359-1372. [CrossRef]

41. Devlaeminck, R.; de Schrijver, A.; Hermy, M. Variation in through-fall deposition across a deciduous beech (Fagus sylvatica L.) forest edge in Flanders. Sci. Total. Environ. 2005, 337, 241-252. [CrossRef]

42. Rothe, A.; Huber, C.; Kreutzer, K.; Weis, W. Deposition and soil leaching in stands of Norway spruce and European beech: Results from the Höglwald research in comparison with other European case studies. Plant Soil. 2002, 240, 33-45. [CrossRef]

43. Fober, H. Mineralne Żywienie W: Białobok St. [red.]. Buk Zwyczajny (Fagus sylvatica L.); PWN Warszawa: Poznaniu, Poland, 1990. (In Polish)

44. Le Tacon, F.; Toutain, F. Variations saisonnières et stationnelles de la teneur en éléments minéraux des feuillesde hêtre (Fagus sylvatica) dans l'est de la France. In Annales des Sciences Forestières; EDP Sciences: Les Ulis, France, 1973; Volume 30, pp. 1-29.

45. Timbacher, C.; Weiss, P. Needle surface characteristics and element contents of Norway spruce in relation to the distance of emission sources. Environ. Pollut. 1999, 105, 111-119. [CrossRef]

46. Shen, W.; Ren, H.; Jenerette, G.D.; Hui, D.; Ren, H. Atmospheric deposition and canopy exchange of anions and cations in two plantation forests under acid rain influence. Atmos. Environ. 2013, 64, 242-250. [CrossRef]

47. Huber, C.; Kreutzer, K. Three years of continuous measurements of atmospheric ammonia concentrations over a forest stand at the Höglwald site in southern Bavaria. Plant Soil 2002, 240, 13-22. [CrossRef]

48. Neirynck, J.; Janssens, A.I.; Roskams, P.; Quataret, P.; Verschelde, P.; Ceulemans, R. Nitrogen biogeochemistry of a mature Scots pine forest subjected to high nitrogen loads. Biogeochemistry 2008, 91, 201-222. [CrossRef]

49. Cao, R.; Chen, S.; Yoshitake, S.; Ohtsuka, T. Nitrogen deposition and responses of forest structure to nitrogen deposition in a cool-temperate deciduous forest. Forests 2019, 10, 631. [CrossRef]

50. Seo, M.; Lee, S.Y.; Lee, C.; Cho, S.S. Recycling of Cement Kiln Dust as a Raw Material for Cement. Environments 2019, 6, 113. [CrossRef]

51. Maslehuddin, M.; Al-Amoudi, O.S.B.; Shameem, M.; Rehman, M.K.; Ibrahim, M. Usage of cement kiln dust in cement products-Research review and preliminary investigations. Constr. Build. Mater. 2008, 22, 2369-2375. [CrossRef]

52. Siddique, R. Cement Kiln Dust. In Waste Materials and By-Products in Concrete; Springer: Berlin/Heidelberg, Germany, 2008. [CrossRef]

53. Uliasz-Bocheńczuk, A. Chemical characteristics of dust from cement kilns. Miner. Resour. Manag. 2019, 35, 87-102. [CrossRef]

54. Pajuste, K.; Frey, J.; Asi, E. Interactions of atmosferic deposition with coniferous canopies in Estonia. Environ. Monit. Assess. 2006, 112, 177-196. [CrossRef] [PubMed]

55. Ots, K.; Mandre, M. Monitoring of heavy metals uptake and allocation in Pinus sylvestris organs in alkalised soil. Environ. Monit. Assess. 2012, 184, 4105-4117. [CrossRef] [PubMed]

56. Golobočanin, D.; Žujić, A.; Milenković, A.; Miljević, N. Precipitation composition and wet deposition temporal pattern in Central Serbia for the period from 1998 to 2004. Environ. Monit. Assess. 2008, 142, 185-198. [CrossRef] [PubMed]

(C) 2020 by the authors. Licensee MDPI, Basel, Switzerland. This article is an open access article distributed under the terms and conditions of the Creative Commons Attribution (CC BY) license (http://creativecommons.org/licenses/by/4.0/). 